FOCUS: Journal of International Business Volume 4, Issue 1, January-June 2017, pp. 1-25 doi: 10.17492/focus.v4i01.9539

\title{
Augmented Footprint of Free Trade Agreements (FTAs) in India: An Empirical Analysis of Indian Chemical Industry
}

\author{
S. P. Sharma* and Rohit Singh**
}

\begin{abstract}
Chemical industry plays a vital role in the functioning of most of the key sectors of an economy which includes agriculture, infrastructure, healthcare, textiles among others. This paper attempts to analyse the dynamics of international trade in chemical sector both at the macro and micro level for the period 2012, 2013 and 2014. The study has also looked into export potential and competitiveness of Indian chemical products in international market with special emphasis to FTA markets. An attempt is also made to study in depth the trade structure of these products, how far erosion of protection is pronounced and the extent FTA partners are responsible for India's rising imports. In case of implication of FTA, erosion of 'effective rate of protection' has been looked into. Further, several trade indices have been calculated both on import and export data to understand quality of exported and imported products, possibility of exploiting economies of scale, extensive and intensive margins, degree of concentration both at product and country level, revealed comparative advantage and possibility of intraindustry trade. The paper conducts an in-depth analysis on selected products to demystify the strengths, weaknesses, opportunities, and threats to Indian chemical industry in the world, especially putting the lens on various FTA groups.
\end{abstract}

Keywords: Chemical industry; Effective rate of protection; Export competitiveness; Revealed comparative advantage; Free Trade Agreements.

\subsection{Introduction}

The Indian chemical industry has witnessed normal growth in the past decade. Indian chemical industry has been ranked $10^{\text {th }}$ largest industry in the world in terms of chemical sales. As per UN COMTRADE database, India ranks $14^{\text {th }}$ in terms of total exports and $8^{\text {th }}$ in terms of total imports from the world.

*Corresponding author; Chief Economist, PHD Chamber of Commerce and Industry, Delhi, India (Email id: spsharma@phdcci.in)

** Research Associate, PHD Chamber of Commerce and Industry, Delhi, India (Email id: rohit.singh@phdcci.in) 
2 | FOCUS: Journal of International Business, Volume 4, Issue 1, January-June 2017

It is also ranked $3^{\text {rd }}$ largest in Asia as per United Nation Industrial Development Organization (UNIDO). As far as global market size of this industry is concerned, it is estimated to reach around USD 5.1 trillion by 2018 with a growth rate of 5-6 per cent per annum over the next decade. Indian chemical industry currently accounts for only 3 per cent of the world chemical market. Figure 1 depicts the total capacity and production of major chemical products in India. India's chemical production has increased from 8380 thousand MT in 2007-2008 to 9632 thousand MT in 2014-2015 at a low CAGR of 2.01 per cent (Chemicals and Petrochemical Statistics at a Glance, 2016).

Figure 1: Performance of Major Chemicals

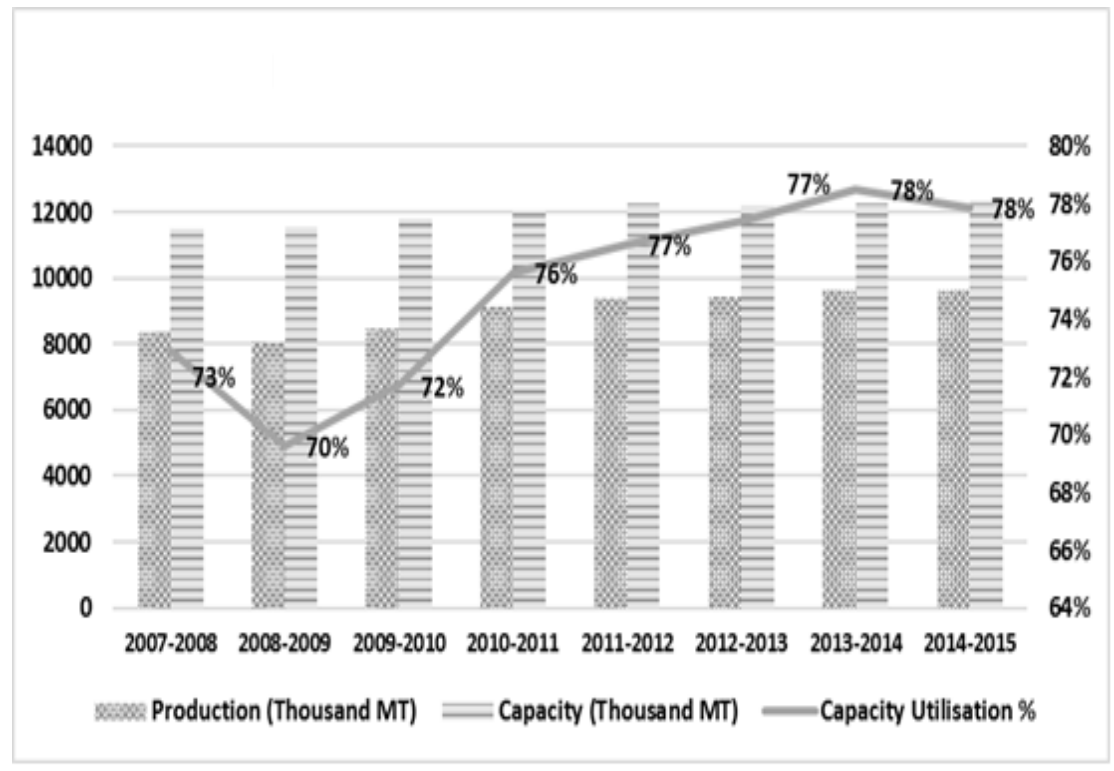

Source: Chemicals \& Petrochemical Statistics at a Glance, 2016

The production capacity has also increased at a very low CAGR of 1.05 per cent during the same period although it was found that the capacity utilization has increased from 73 per cent in 2007-2008 to 78 per cent during 2014-2015. The total export of chemical products has increased from 675 thousand MT in 2007-2008 to 1061 thousand MT in 2014-2015 at a CAGR of 6.69 per cent, the share of India's exports in 2014 for all HS commodities in the world is estimated at 1.79 per cent as compared to 2.64 per cent in world's imports. 


\subsection{Literature Review}

There is not a profound literature related to the trade structure of chemical industry in India and at global level. Notably, no such exhaustive research paper has been prepared in the recent past. Although studies are conducted on broader trade environment, but none of them focuses at disaggregated product level. Having said that, the essence of this paper is its robust approach wherein product level analysis has been conducted utilizing highly acclaimed international trade feasibility indices. Few studies have been made in the recent past to analyse the chemical industry and its trade structure in India, some of which have been reviewed below.

Bhat, Savita \& Narayanan (2009) have made an attempt to examine the role of technological efforts and firm size in determining the export behaviour of firms belonging to the basic chemical industry in India. It highlighted that basic chemical industry is an important industry that provides intermediate chemicals to firms operating in diverse industries in both India and abroad. In addition, Dhanisha and Johnson (2015) have made an attempt to know the contribution of chemical industry in economic development of India and to examine the safety measures implemented by chemical industries in India and the paper also visualise the production performance of developing and developed regions. The paper reveals that the chemical sector has made tremendous strides to boost the economic front of India.

\subsection{Chemicals Exports and Imports of India}

The total exports of five categories have increased from 3524 USD million in 2012 to 4294 USD million in 2014 at a CAGR of 10.38 per cent (Table 1). Additionally, this growth was pushed by the growth in pesticides and insecticides (17.3 per cent), organic chemicals (17.16 per cent), and inorganic chemicals (1.06 per cent) by the ardent importers all around the world. However, the robust growth contributed by the aforementioned chemicals was abated by a decline in growth of alkali chemicals (-25.94 per cent) and dyes and pigments (-24.68 per cent). It has been found that more than 80 per cent of total chemical exports are shared between organic chemicals and pesticides and insecticides.

The shares of different categories of chemicals over the years, the share of pesticides and insecticides exports have increased from 38.1 per cent in 2012 to 43 per cent in 2014. The share of inorganic chemicals declined from 15.6 per cent in 2012 to 13.2 per cent in 2014. The share of dyes and pigments and alkali chemicals also reduced over the period, the share of dyes and pigments declined from 9.6 per cent in 2012 to 4.5 
4 | FOCUS: Journal of International Business, Volume 4, Issue 1, January-June 2017

per cent in 2014 showing a decline of around 5 per cent in the period of three years, in the dyes \& pigments exports more than 75 per cent of the share is devoted to exports of Azo Dyes, Reactive Dyes and Pigment Emulsion. The share of alkali chemicals also declined from 3.1 per cent in 2012 to 1.4 per cent in 2014.

Table 1: Exports Value of Different Chemicals

\begin{tabular}{|l|c|c|c|c|}
\hline $\begin{array}{c}\text { Chemicals (Exports) } \\
\text { Values in USD million }\end{array}$ & $\mathbf{2 0 1 2}$ & $\mathbf{2 0 1 3}$ & $\mathbf{2 0 1 4}$ & CAGR \\
\hline Alkali Chemicals & 107.71 & 61.7 & 59.08 & $-25.94 \%$ \\
\hline Dyes and Pigments & 338.09 & 182.25 & 191.8 & $-24.68 \%$ \\
\hline Inorganic Chemicals & 549.33 & 686.03 & 567.04 & $1.60 \%$ \\
\hline Organic Chemicals & 1186.38 & 1459.39 & 1628.35 & $17.16 \%$ \\
\hline Pesticides and Insecticides & 1343.48 & 1461.98 & 1848.54 & $17.30 \%$ \\
\hline TOTAL & $\mathbf{3 5 2 4 . 9 9}$ & $\mathbf{3 8 5 1 . 3 5}$ & $\mathbf{4 2 9 4 . 8 1}$ & $\mathbf{1 0 . 3 8 \%}$ \\
\hline
\end{tabular}

Source: India Trades CMIE Database

The total imports of five categories have increased from 2718 USD million in 2012 to 3192 USD million in 2014 at a CAGR of 8.37 per cent (Table 2). The growth in the total annual imports was a result of a high annual import growth of alkali chemicals (12.51 per cent), organic chemicals (10.27 per cent), pesticides and insecticides ( 7.18 per cent), dyes and pigments (5.92 per cent) and inorganic chemicals (3.46 per cent), the largest share in imports among all the categories is of organic chemicals which has remained between 46 per cent to 49 per cent from 2012 to 2014. The share of alkali chemicals imports has remained between 7 per cent and 10 per cent from 2012 to 2014, in the alkali chemicals import caustic soda and soda ash has nearly 99 per cent share, the import of caustic soda increased from 89.27 USD million in 2012 to 120 USD million in 2014.

Table 2: Imports Value of Different Chemicals

\begin{tabular}{|l|c|c|c|c|}
\hline $\begin{array}{c}\text { Chemicals (Imports) } \\
\text { Values in USD million }\end{array}$ & $\mathbf{2 0 1 2}$ & $\mathbf{2 0 1 3}$ & $\mathbf{2 0 1 4}$ & CAGR \\
\hline Alkali Chemicals & 199.76 & 317.14 & 252.85 & $12.51 \%$ \\
\hline Dyes and Pigments & 323.36 & 352.26 & 362.79 & $5.92 \%$ \\
\hline Inorganic Chemicals & 410.5 & 435.9 & 439.4 & $3.46 \%$ \\
\hline Organic Chemicals & 1301.22 & 1378.74 & 1582.2 & $10.27 \%$ \\
\hline Pesticides and Insecticides & 483.49 & 484.19 & 555.36 & $7.18 \%$ \\
\hline TOTAL & $\mathbf{2 7 1 8 . 3 3}$ & $\mathbf{2 9 6 8 . 2 3}$ & $\mathbf{3 1 9 2 . 6}$ & $\mathbf{8 . 3 7 \%}$ \\
\hline
\end{tabular}

Source: India Trades CMIE Database 
The import share of dyes and pigments has remained around 11 per cent from 2012 to 2014 among the five categories, the CAGR of dyes and pigment imports was 5.92 per cent from 2012 to 2014, the largest import share in this category in 2014 was of pigment emulsion ( 21 per cent), vat dyes (16.81 per cent) and disperse dyes (15.12 per cent). The import share of inorganic chemicals declined from 15.10 per cent in 2012 to 13.75 per cent in 2014, the CAGR of inorganic chemicals was recorded as the lowest among the five categories which is 3.46 per cent, the largest import share in inorganic chemicals in 2014 was of carbon black (42.44 per cent), calcium carbonate (17.52 per cent), titanium dioxide (10.98 per cent) and calcium carbide (10.06 per cent).

The import of organic chemicals increased from 1301.22 million USD in 2012 to 1582.2 million USD in 2014 at a CAGR of 10.27 per cent, the share of organic chemicals among all the five categories was 49.56 per cent in 2014. The largest import share in the organic chemicals in 2014 was of menthol (35.74 per cent), acetic acid (20.69 per cent), phenol (18.03 per cent) and acetone ( 8.51 per cent). Some of the major exporting countries of organic chemicals to India are Taiwan, China, Saudi Arabia, Iran, Singapore, USA, Thailand and Malaysia. By analysing the import structure for organic chemicals it can be said that India is importing mostly from non FTA countries.

The import of pesticides and insecticides increased from 483.49 million USD in 2012 to 555.36 million USD in 2014, the share of pesticides and insecticides among all the five categories of chemicals has remained around 17 per cent from 2012 to 2014. The largest import share in the pesticides and insecticides in 2014 was of other insecticides (57.90 per cent), Other Herbicides- Anti sprouting products (25.59 per cent), and other fungicides (11.81 per cent). Some of the major exporting countries of organic chemicals to India are China, USA, Germany, UK, Switzerland and Japan.

\subsection{An Intensive Analysis of India's Chemical Imports}

At present, despite being one of the oldest industries in Indian history, the trade structure reflects as if a lot is needed to enhance the capacity building and accentuate the efficiency level. This nascent reflection of an already developed chemical industry, primarily due to dearth of raw materials and indispensable intermediates, led to the rise in imports from across the globe over the years at an unprecedented rate. It is essential for the development of a nation to be self-sufficient for its domestic demand and at the same time contribute enough to mark its presence in the global value chain. Imports are an inevitable result of being a globalised for one of the fastest growing economy, especially in strategically vital sectors such as chemical. 
6 | FOCUS: Journal of International Business, Volume 4, Issue 1, January-June 2017

\subsection{Methodology}

India's demand for chemical imports has registered a rise which is resulting in huge outflow of funds and also impacting the economy because of domestic producer's inability to produce relatively economical chemical products. It is also noticed that India has signed number of FTAs with possible large exporters of these products during this time viz. Japan, Korea Republic, ASEAN etc. India's duty difference between final and intermediate goods has also narrowed down leading to loss of effective protection which is further accentuated by these FTAs. With this background, the paper intends to study in-depth the trade structure of these products, how far erosion of protection is pronounced and the extent FTA partners are responsible for India's rising imports. To effectively gauge the effect of FTA's on the import of chemicals, the paper has undertaken calculation of certain indicators. Before moving ahead with the measurement of various indicators and analysis of import segment, we delineated various chemical products based on a predetermined benchmark. Here, the benchmark has been fixed according to the value of imports. Products crossing the threshold limit of USD 100 million in either 2012, 2013 or 2014 are considered for further critical analysis.

\subsection{Erosion of Effective Rate of Protection (ERP)}

The ERP is an indicative measure of the impact of protection on producers. It provides the percentage rise in domestic value added over the free-trade level, an increase made possible by the country's tariff structure. Value added is the difference between the total value of goods produced and the value of imported inputs and represents the amount of money paid to the domestic factors of production. In other words, ERP of product $i$ is defined as the difference between its value added (per unit of output) at domestic price, (i.e., inclusive of tariffs on the finished product and the intermediate inputs) and its corresponding value added at world price (i.e., price prevailing under free trade).

Thus, (ignoring the prices of final and intermediate goods) ERP can be represented as

$$
e_{i}=\frac{t_{j}-\sum_{i=1}^{n} a_{i j} t_{i}}{1-\sum_{i=1}^{n} a_{i j}}
$$

Here, $a_{i j}$ is the ratio of the cost of imported input $i$ to the price of final commodity $j$ net of tariffs

$t_{j}$ is the nominal rate of tariff on final good $j$

$t_{i}$ is the nominal rate of tariff on good $i$ (input)

Production of chemical products require large number of inputs. We have separated the inputs into chemical and non-chemical inputs as given below: 


$$
e_{i}=\frac{t_{j}-\sum_{i=1}^{k} a_{i j}^{p} t_{i}^{p}-\sum_{i=1}^{m} a_{i j}^{q} t_{i}^{q}}{1-\sum_{i=1}^{n} a_{i j}}
$$

where $\mathrm{n}=\mathrm{k}+\mathrm{m}$,

Total number of inputs (n) is divided into two groups: chemical inputs ( $\mathrm{k}$ in numbers) and others ( $\mathrm{m}$ in numbers). As a result equation (1) is converted into equation (2) where $\mathrm{p}$ and $\mathrm{q}$ are used to differentiate tariffs and input coefficients for chemical and other inputs.

Currently we are concerned with FTA impact on the chemical sector only. Hence, we consider the impact on other inputs due to FTA as constant. So we write equation (2) as

$$
\begin{aligned}
& e_{i}=\frac{t_{j}-\sum_{i=1}^{k} a_{i j}^{p} t_{i}^{p}}{1-\sum_{i=1}^{n} a_{i j}}-C \\
& e_{i}=\mathrm{Z}_{\mathrm{ij}}-\mathrm{C}, \quad \text { where } \mathrm{C}=\frac{\sum_{i=1}^{m} a_{i j}^{p} t_{i}^{p}}{1-\sum_{i=1}^{n} a_{i j}}
\end{aligned}
$$

Hence, the erosion of protection due to FTA can be calculated as

$e_{j M F N}-e_{j F T A}=Z_{i j M F N}-Z_{i j}$ FTA

It is a general perception that sectors which have lower value addition are facing more competition and perhaps more liberalised. From Table 3, it is clear that dyes, pigments and pesticides have higher value added compared to other sectors.

Table 3: Industry Value Addition in Selected Chemicals (2014)

\begin{tabular}{|l|c|c|c|c|}
\hline \multicolumn{1}{|c|}{ Chemicals } & Total Input & $\begin{array}{c}\text { Net Indirect } \\
\text { Taxes }\end{array}$ & $\begin{array}{c}\text { Gross Value } \\
\text { Added }\end{array}$ & $\begin{array}{c}\text { Total } \\
\text { Output }\end{array}$ \\
\hline $\begin{array}{l}\text { Dyes and Pigments } \\
\text { Paints, Varnishes \& Lacquers) }\end{array}$ & 62.74 & 4.23 & 33.03 & 100.00 \\
\hline Pesticides & 73.30 & 2.89 & 23.81 & 100.00 \\
\hline Inorganic Chemicals & 78.09 & 2.20 & 19.71 & 100.00 \\
\hline Organic Chemicals & 77.50 & 3.59 & 18.91 & 100.00 \\
\hline
\end{tabular}

Note: Using data on Input coefficients (aij) from India's last Input-Output (I-O) table, 2007-08 .

Source: Authors' calculations; Values in percentages

ERP indicates the overall protection a sector enjoys due to differentials among tariffs of final goods vis-à-vis intermediate and raw materials. Due to FTA, there are erosion of effective rate of protection. Different countries have received advantages in different products. In dyes and pigments, average final good duty is zero while importing 
from Thailand leading to high erosion of protection (Table 4). Protection is also low while importing from Singapore. Japan has distinct advantage in exporting organic chemicals. Malaysia has huge advantage in exporting inorganic and organic chemicals. Among all FTA partners, duty reduction is very low on imports from South Korea. In fact, in some cases, FTA duty on South Korea is more than even MFN effective rate. We have noted in Table 4 that South Korea has received price advantage mostly. FTA advantage has gone in favour of Malaysia and Japan in some cases and also to Singapore and Thailand (Table 4).

Table 4: Erosion of Effective Rate of Protection under FTA vis-à-vis MFN duty (2014)

\begin{tabular}{|c|c|c|c|c|c|c|}
\hline Chemicals & $\begin{array}{c}\text { Share of } \\
\text { Chemical inputs } \\
\text { in the production }\end{array}$ & 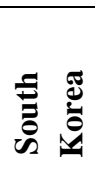 & 总 & 莺 & $\frac{\sqrt[\pi]{\frac{\pi}{2}}}{\sum_{\frac{\pi}{\pi}}^{\frac{\pi}{\pi}}}$ & 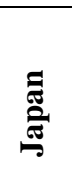 \\
\hline $\begin{array}{l}\text { Dyes and Pigments } \\
\text { (Paints, Varnishes \& Lacquers) }\end{array}$ & $36.7 \%$ & & $18.6 \%$ & $17.6 \%$ & & \\
\hline Pesticides & $45.0 \%$ & & & $13 \%$ & & $21 \%$ \\
\hline Inorganic Chemicals & $44.9 \%$ & $-4 \%$ & & & $23.2 \%$ & \\
\hline Organic Chemicals & $37.0 \%$ & $-4 \%$ & & $18 \%$ & $23.0 \%$ & $12 \%$ \\
\hline
\end{tabular}

Source: Authors' calculations; Values in percentages

\subsection{Quality Margin of imports from various countries in India}

The quality margin map comprises of four quadrants so as to identify the prima facie treatment of imports from various countries. To evaluate overall quality and sophistication of the major chemical imports, Quality Margin Map has been formulated to determine the position of the top five countries present in Indian market (Table 5). The data used is for the period 2012-2014. Assuming unit value as a benchmark for quality, India treats import of Methanol (290511) from Brunei and Iran as high quality product. The performance of Saudi Arabia and Oman has fallen for 290511 exports to India despite ranked in the top five exporting markets to India. Imports of Acetic acid (291521) have remained consistently high in India's trade books. Singapore and Taipei turned out to be the top markets, with ever increasing market share in India despite an exorbitant rise in the unit value of 291521. In this regard, India perceives it as a high quality product. For rodenticides and other plant protection products (380899), imports from Singapore and China are considered as high quality products. Especially from Singapore, market share has remained consistently high despite huge rise in unit value. 
Thailand, South Africa and Singapore are on the top-right quadrant of the QM map for Phenol (hdroxybenzene) and its salts (290711) imports in India during 2012 and 2014. For imports of Insecticides (380891), China has been categorized as high quality exporter due to a significant increase in unit value, imports remained positive.

Table 5: Summary of Quality Margin of Major Chemicals

\begin{tabular}{|c|c|c|c|c|}
\hline Products & High Quality & $\begin{array}{c}\text { Innovation, } \\
\text { Economies of scale } \\
\text { at work }\end{array}$ & $\begin{array}{c}\text { Decrease in } \\
\text { Competitiveness }\end{array}$ & $\begin{array}{l}\text { Death of } \\
\text { the product }\end{array}$ \\
\hline \multirow{3}{*}{290511} & Iran & & Saudi Arabia & \multirow{3}{*}{$\begin{array}{l}\text { South } \\
\text { Korea }\end{array}$} \\
\hline & Brunei & & Omon & \\
\hline & Indonesia & & mant & \\
\hline \multirow{2}{*}{291521} & Singapore & & Saudi Arabia & \multirow{2}{*}{ China } \\
\hline & Taipei & & Malaysia & \\
\hline \multirow{2}{*}{380899} & Singapore & & \multirow{2}{*}{ Japan } & Germany \\
\hline & China & & & USA \\
\hline \multirow{3}{*}{290711} & Thailand & & \multirow{3}{*}{ Taipei } & \\
\hline & South Africa & South Korea & & \\
\hline & Singapore & & & \\
\hline \multirow{2}{*}{380891} & \multirow{2}{*}{ China } & Japan & \multirow{2}{*}{ USA } & \multirow{2}{*}{ Germany } \\
\hline & & Singapore & & \\
\hline
\end{tabular}

Source: Authors' calculations

\subsection{An Intensive Analysis of India's Exports of Chemical Products}

India exported chemicals valuing USD 4294.81 million at a CAGR of 10.38 per cent in 2014. In Chemical segment, export growth was primarily pulled by jump in exports of organic chemicals, inorganic chemicals and pesticides and insecticides. However, this climb was bottlenecked by sharp fall in export of alkali chemicals and dyes and pigments by a near 25 per cent between 2012 and 2014 .

For the rejuvenation of Indian chemical industry, there is a need to enhance the quality level of products and to expedite the process by working at economies of scale. India exports approximately 50 per cent of its current production of agro chemicals representing the key component of chemical export growth. Chemical sector is one of the most diversified sectors, covering more than 70,000 commercial products. Similar path needs to be built for other essential chemicals so as to develop a bigger footprint in 
the global value chain. With various FTA partners and various negotiations in place, India has the capability to expand its presence in those markets and simultaneously look for inclusion of newer markets in the market base India already exports to.

\subsection{Methodology}

A holistic analysis of sector helps in achieving an overall and concentrated results and explanations of the current scenario and further assists in formalising a hypothesis for the future of the selected sector such as forming policy framework, rules and regulations. To begin our crucial analysis of chemical sector, we underwent following steps:

- The pre-requisite step is to identify the various products from the innumerable list wherein they have highest level of exports. Due to vast number of chemicals being exported and to primarily focus our analysis towards the impact of FTAs, the chemical group has been delineated into 23 HS-06 codes.

- To move ahead with the analysis section, we have delineated 23 major chemicals at HS-06 code from the overall chemicals basket based on the value of exports greater than USD 20 million either in 2012, 2013 or 2014.

The objective of the following analysis is to demystify the strengths, weaknesses, opportunities, and threats to Indian chemical industry in the world, especially putting the lens on various FTA groups. Further, the export potentiality and competitiveness of chemicals from India is measured with special emphasis given to FTA partners. The various indicators that are considered and calculated for our study hereon have been presented in Table 6.

Table 6: Definitions and Explanations of Indicators Used

\begin{tabular}{|c|c|c|}
\hline \multicolumn{3}{|c|}{ 1) Revealed Comparative Advantage } \\
\hline $\begin{array}{l}\text { Definition } \\
\text { Revealed comparative } \\
\text { advantage (RCA) index } \\
\text { use the trade pattern to } \\
\text { identify the sectors in } \\
\text { which an economy has a } \\
\text { comparative advantage, } \\
\text { by comparing the } \\
\text { country's interests' trade } \\
\text { profile with the world } \\
\text { average. }\end{array}$ & $\begin{array}{l}\text { Mathematical explanation } \\
\mathrm{RCA}_{i j}=\frac{x_{i j}}{x_{w j} / X_{w}} \\
\text { Here, } \\
\mathrm{i}=\text { country of interest } \\
\mathrm{j}=\text { sector of interest } \\
\mathrm{w}=\text { all the countries in the } \\
\text { world } \\
\mathrm{x}=\text { Exports of } \mathrm{j} \\
\mathrm{X}=\text { Total exports }\end{array}$ & $\begin{array}{l}\text { Results interpretation } \\
\text { Range: } 0 \leq \mathrm{RCA} \leq+\infty, \\
\text { If value exceeds unity, the country } \\
\text { is said to have revealed } \\
\text { comparative advantage. }\end{array}$ \\
\hline
\end{tabular}




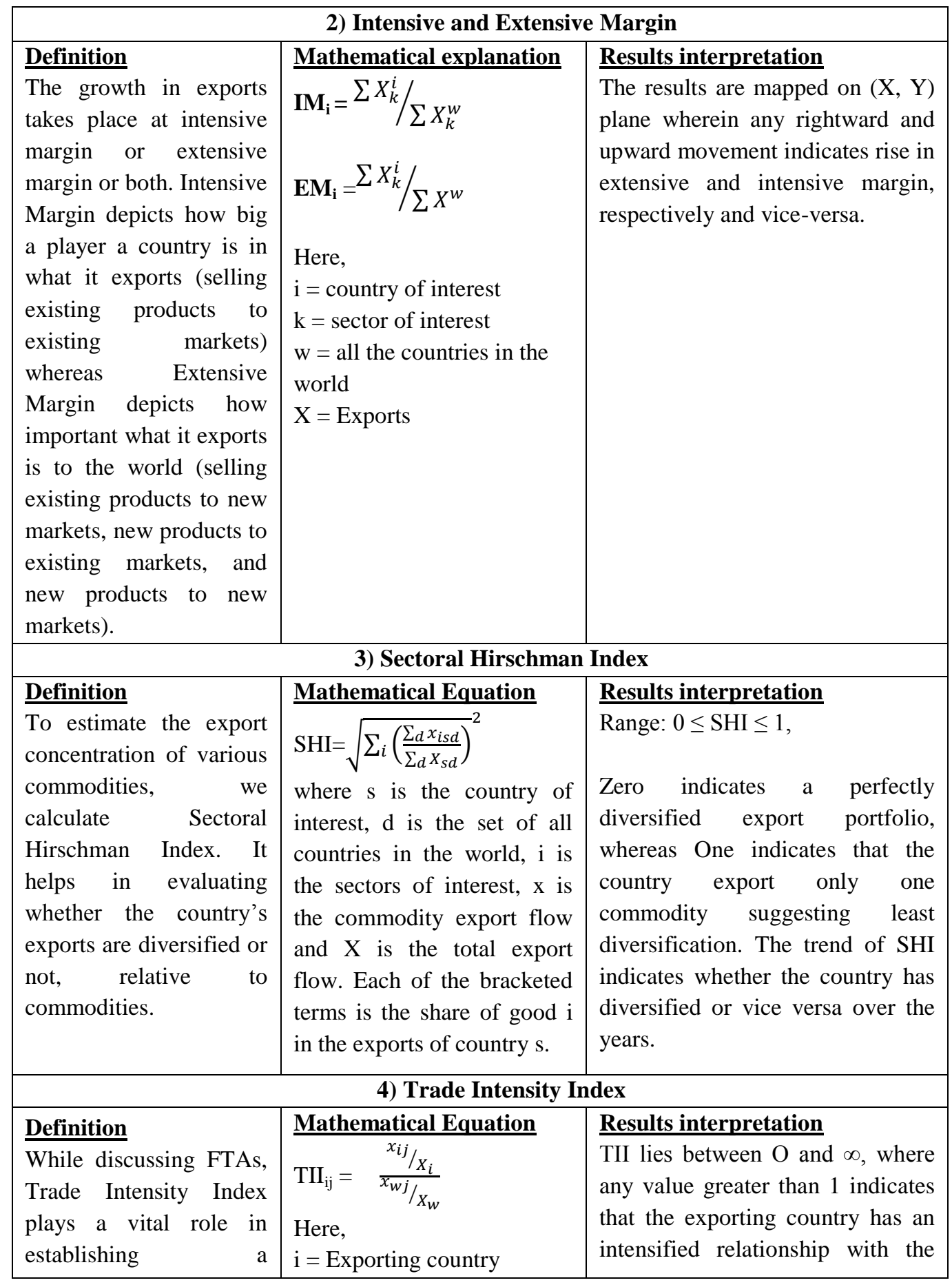




\begin{tabular}{|c|c|c|}
\hline $\begin{array}{l}\text { relationship between } \\
\text { country's trading } \\
\text { footprint in his trading } \\
\text { partner's economy. } \\
\text { TII measures the } \\
\text { presence of country's } \\
\text { exports in its trading } \\
\text { partner's economy. It is } \\
\text { measured as country } i \text { 's } \\
\text { exports to country } j \\
\text { relative to its total } \\
\text { exports divided by the } \\
\text { world's exports to } \\
\text { country } j \text { relative to the } \\
\text { world's total exports. }\end{array}$ & $\begin{array}{l}\mathrm{j}=\text { Importing country } \\
\mathrm{w}=\text { all the countries in the } \\
\text { world } \\
\mathrm{X}=\text { Exports }\end{array}$ & importing country. \\
\hline \multicolumn{3}{|c|}{ 5) Regional Hirschman Index } \\
\hline $\begin{array}{l}\text { Definition } \\
\text { To estimate the export } \\
\text { concentration of various } \\
\text { commodities, we } \\
\text { calculate Regional } \\
\text { Hirschman Index. It } \\
\text { helps in evaluating } \\
\text { whether the country's } \\
\text { exports are diversified or } \\
\text { not, concentrating on } \\
\text { export markets only. }\end{array}$ & $\begin{array}{l}\text { Mathematical Equation } \\
\text { RHI }=\sqrt{\sum_{d}\left(\frac{\sum_{s} x_{s d}}{\sum_{s w} X_{s w}}\right)^{2}} \\
\text { where } \mathrm{s} \text { is the set of source } \\
\text { countries under study, } \mathrm{d} \text { is } \\
\text { the set of destinations, w is } \\
\text { the set of countries in the } \\
\text { world, and } \mathrm{X} \text { is the bilateral } \\
\text { flow of exports from the } \\
\text { source to the destination. We } \\
\text { want to sum over all } \\
\text { destinations, so the sets } \mathrm{d} \\
\text { and w contain the same } \\
\text { elements. }\end{array}$ & $\begin{array}{l}\text { Results interpretation } \\
\text { Range: } 0 \leq \mathrm{RHI} \leq 1, \\
\text { Zero indicates a perfectly } \\
\text { diversified export portfolio, } \\
\text { whereas one indicates that the } \\
\text { country export only to one country } \\
\text { suggesting least diversification. } \\
\text { The trend of RHI indicates } \\
\text { whether the country has } \\
\text { diversified or vice versa over the } \\
\text { years. }\end{array}$ \\
\hline \multicolumn{3}{|c|}{ 6) Quality Margin } \\
\hline $\begin{array}{l}\text { Definition } \\
\text { It identifies products } \\
\text { based on their unit value } \\
\text { and market share in the } \\
\text { world. It indirectly } \\
\text { estimates the quality of } \\
\text { product, using unit value } \\
\text { as a measure. }\end{array}$ & $\begin{array}{l}\text { Mathematical Equation } \\
\text { Change in Unit value and } \\
\text { Market share overtime is } \\
\text { plotted on a map. The } \\
\text { position of coordinate of the } \\
\text { product }(\mathrm{X}, \mathrm{Y} \text { ) determines } \\
\text { the quality of product. } \\
\mathrm{X} \text {-axis: } \Delta \text { in Market Share } \\
\text { Y-axis: } \Delta \text { in Unit Value }\end{array}$ & $\begin{array}{l}\text { Results interpretation } \\
\text { Coordinates }(\mathrm{X}, \mathrm{Y}) \text { are mapped on } \\
\text { a 4-quadrant zone. } \\
\text { Top-left: Fall in competition } \\
\text { Top-right: High Quality } \\
\text { Bottom-left: Death of product } \\
\text { Bottom-right: Innovation, } \\
\text { economies of scale }\end{array}$ \\
\hline
\end{tabular}




\begin{tabular}{|c|c|c|}
\hline \multicolumn{3}{|c|}{ 7) Grubel-Lloyd Index } \\
\hline $\begin{array}{l}\text { Definition } \\
\text { It is an indicator to } \\
\text { measure the scale of } \\
\text { intra industry trade. This } \\
\text { index in pertinent for } \\
\text { countries seeking to } \\
\text { diversify exports not } \\
\text { across industries but } \\
\text { rather within an industry. }\end{array}$ & $\begin{array}{l}\text { Mathematical Equation } \\
\text { GLI }=1-\frac{\sum\left|X_{i}-M_{i}\right|}{\sum\left(X_{i}+M_{i}\right)} \\
\text { where, } \\
\mathrm{i}=\text { Country of interest } \\
\mathrm{X}=\text { Exports } \\
\mathrm{M}=\text { Imports }\end{array}$ & $\begin{array}{l}\text { Results interpretation } \\
\text { Range: } 0 \leq \mathbf{G L I} \leq 1 \text {, } \\
G L_{i}=1 \text {, there is only intra- } \\
\text { industry trade, no inter-industry } \\
\text { trade. This means for example the } \\
\text { Country in consideration Exports } \\
\text { the same quantity of good } i \text { as } \\
\text { much at it Imports. Conversely, if } \\
G L_{i}=0 \text {, there is no intra-industry } \\
\text { trade, only inter-industry trade. } \\
\text { This would mean that the Country } \\
\text { in consideration only either } \\
\text { Exports or only Imports good } i \text {. }\end{array}$ \\
\hline
\end{tabular}

\subsection{Skewed Dominance: Revealed Comparative Advantage}

India's performance in some of the chemicals has been commendable such as in Dyes and Pigments. In the chemical segment, the major 23 HS-06 under the chemicals category comprises of 98 per cent of the total chemical exports from India (Table 7). India exhibits high RCA for various Dyes and pigments such as Synthetic Organic Acid Dyes (320412), Direct synthetic organic dyes (320414), and Synthetic Organic Reactive Dyes (320416), Synthetic organic pigments (320417), Synthetic organic colouring pigments (320419), Synthetic organic products used as fluorescent brightening agents (320420), Vat dyes and preparations based thereon (320415), Basic Synthetic dyes (320413) and Synthetic organic disperse dyes (320411).

The quality of Dyes made in India meets the exact standards set by International customers. Most Dyes and pigments manufacturing units have in-house testing laboratories and quality control procedures that provide an upper hand to India's exports. The forces behind the high demand for dyes and pigments are growth in end user industries, rising demand for high performance pigments (HPP), and rising preference towards environment friendly products. The last aforementioned reason led to the dramatic shift of the many manufacturing facilities from USA and Europe to India in search for eco-friendly products.

\subsection{Bigger footprint versus lower share: Intensive and extensive margin}

India has been able to fast track on its expansion process as far as chemicals are concerned. Tapping into untapped markets and exploiting the advantage it holds, India entered into newer markets with higher demands for chemicals. However, ostensibly the 
14 | FOCUS: Journal of International Business, Volume 4, Issue 1, January-June 2017

demands were not met by Indian chemical exports. Notwithstanding the covering of more markets in 2014, India's share for both chemicals fell in the overall world exports.

Table 7: RCA of 23 major chemicals

\begin{tabular}{|c|c|c|c|}
\hline Chemicals at HS-06 & 2012 & 2013 & 2014 \\
\hline \multicolumn{4}{|l|}{ Alkali Chemicals } \\
\hline $281511^{\#}$ & 3.326 & 2.888 & 2.096 \\
\hline $283620^{\$}$ & 0.633 & 0.553 & 0.155 \\
\hline \multicolumn{4}{|l|}{ Inorganic Chemicals } \\
\hline $280300^{\wedge}$ & 3.090 & 2.305 & 2.539 \\
\hline $282300^{\$}$ & 0.596 & 0.311 & 0.236 \\
\hline $283650^{\$}$ & 0.255 & 0.236 & 0.293 \\
\hline \multicolumn{4}{|l|}{ Organic Chemicals } \\
\hline $290290^{\wedge}$ & 3.479 & 3.307 & 3.627 \\
\hline $290511^{\$}$ & 0.448 & 0.213 & 0.117 \\
\hline $290611^{\#}$ & 27.203 & 22.970 & 20.447 \\
\hline $291531^{\#}$ & 6.088 & 7.990 & 5.500 \\
\hline \multicolumn{4}{|l|}{ Pesticides and Insecticides } \\
\hline $380891^{\#}$ & 6.856 & 5.933 & 5.339 \\
\hline $380892^{\#}$ & 2.134 & 2.318 & 2.214 \\
\hline $380893^{\#}$ & 1.364 & 1.562 & 1.560 \\
\hline $380899^{\#}$ & 12.900 & 14.019 & 13.428 \\
\hline \multicolumn{4}{|l|}{ Dyes and Pigments } \\
\hline $320411^{\wedge}$ & 2.120 & 2.578 & 3.468 \\
\hline $320412^{\wedge}$ & 12.328 & 13.719 & 15.828 \\
\hline $320413^{\wedge}$ & 5.650 & 6.221 & 6.919 \\
\hline $320414^{\wedge}$ & 11.267 & 12.939 & 15.711 \\
\hline $320415^{\wedge}$ & 5.295 & 4.958 & 6.496 \\
\hline $320416^{\wedge}$ & 16.824 & 18.567 & 20.774 \\
\hline $320417^{\wedge}$ & 6.519 & 6.565 & 6.868 \\
\hline $320419^{\wedge}$ & 6.767 & 7.492 & 8.399 \\
\hline $320420^{\wedge}$ & 7.211 & 6.880 & 7.528 \\
\hline $320649^{\$}$ & 0.906 & 0.793 & 0.332 \\
\hline
\end{tabular}

Note: ${ }^{\wedge}$ denotes HS-06 holds comparative advantage, and has maintained or increased it over the preceding year; \# denotes HS-06 holds comparative advantage, however losing it over the preceding year; $\$$ denotes HS-06 doesn't hold the comparative advantage.

Source: Authors' calculations 
On Intensive and Extensive Margin Map, for major chemicals, India's intensive margin rose from 0.056 in 2012 to 0.062 in 2013, before falling to 0.058 in 2014 exhibiting signs of fall in share of major chemical exports in world's exports of those major chemicals (Figure 2). However, the downward shift in the 2014 coordinated was accompanied by rightward shift in extensive margin as well, denoting a higher number of markets to which the major chemicals were exported and gained a greater importance among all the products exported in the world.

Figure 2: Intensive and Extensive Margin for 23 major chemicals (aggregate view) of India

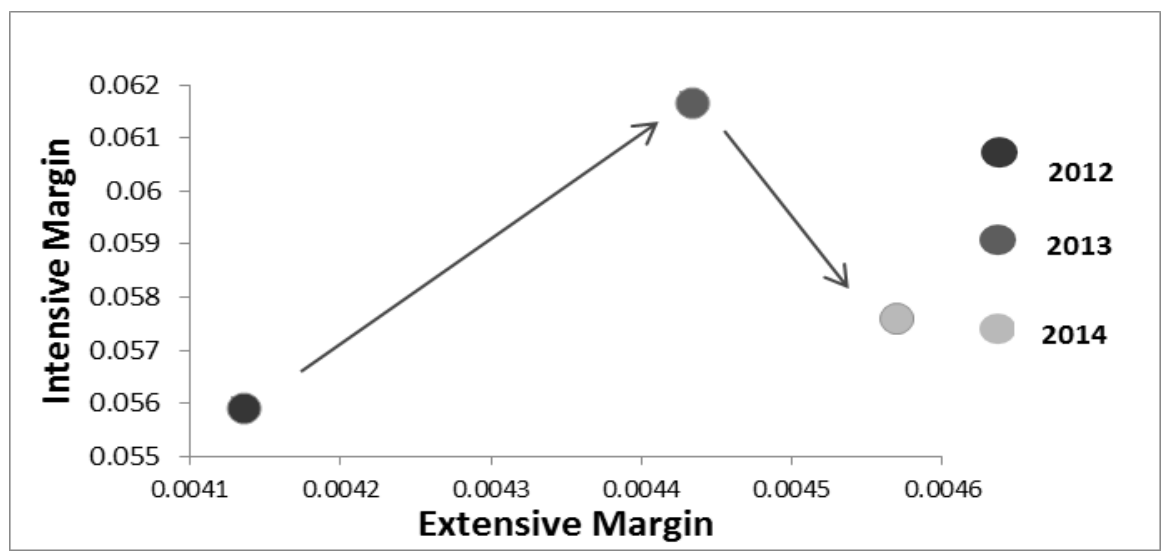

Source: Authors' calculations

\subsection{Marginal presence in the peer FTA groups: Trade Intensity Index (TII)}

India has not been able to sustain the presence of its major chemicals in the markets it has FTA with, not even with the countries it has vicinity. India's TII with major FTA groups has been falling over the years, suggesting the agreement to bolster the trade of chemicals did not pan out beneficial for India (Figure 3). Moreover, with standout economically developed nations such as Japan, South Korea, and Singapore the TII for major chemicals have been further lower and falling. TII with ASEAN and SAARC markets has remained greater than one, but consistently falling. The trade structure and the indices suggest that India has not been able to perform well in its peer FTA partner's markets, especially in Alkali Chemicals with lower than 1 per cent share in the world exports. 
Figure 3: Trade Intensity Index of India for Major Chemicals

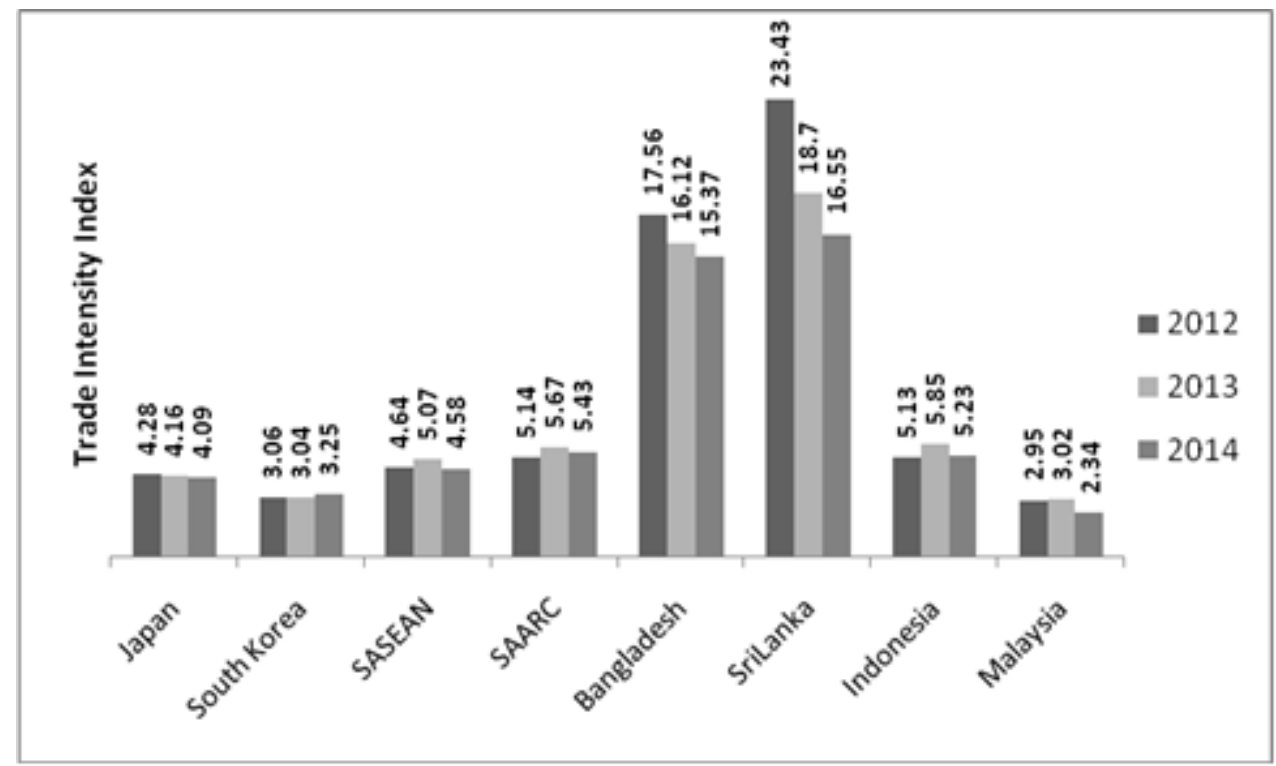

Source: Authors' calculations

\subsection{Lower dependence on fewer markets for exports: Regional Hirschman Index}

The performance of India's major chemicals has grown significantly, in terms of exports to various markets. The RHI barometer indicated that the dependency ratio for exporting major chemicals has actually fallen during the period 2012-2014, thereby indicating low concentration levels and lower vulnerability to economic changes in a small number of export markets (Figure 4). In the major chemicals segment, RHI has been consistently falling since 2012. This fall exhibit a positive change for Indian exports as the demand for major Indian chemicals has seen a spurt from newer markets across the globe.

The substantial development has been in capturing newer markets for Indian chemicals. With the growing demand for Chemicals, being strategically and industrially essential commodities, across the globe, India has been able to supply its major chemicals to 114 markets globally in 2014 (Table 8). The data indicates that the number of markets has risen since 2012, ostensibly true, however India lost a few market also since 2012. Markets to which India didn't export its major chemicals since 2012 are Saudi Arabia, Ghana, Costa Rica, Tunisia, Sudan, Bhutan, Papua New Guinea, Albania and Cambodia. To compensate for this lost opportunity, India exported to markets, which were not on the exporting list in 2012 and 2013, such as Egypt, Ethiopia, Ukraine, 
Cameroon, Malawi, Burundi, Belize, Jamaica, Cape Verde, Republic of Congo, New Caledonia, Tonga, and St. Lucia.

Figure 4: Regional Hirschman Index for major Chemicals

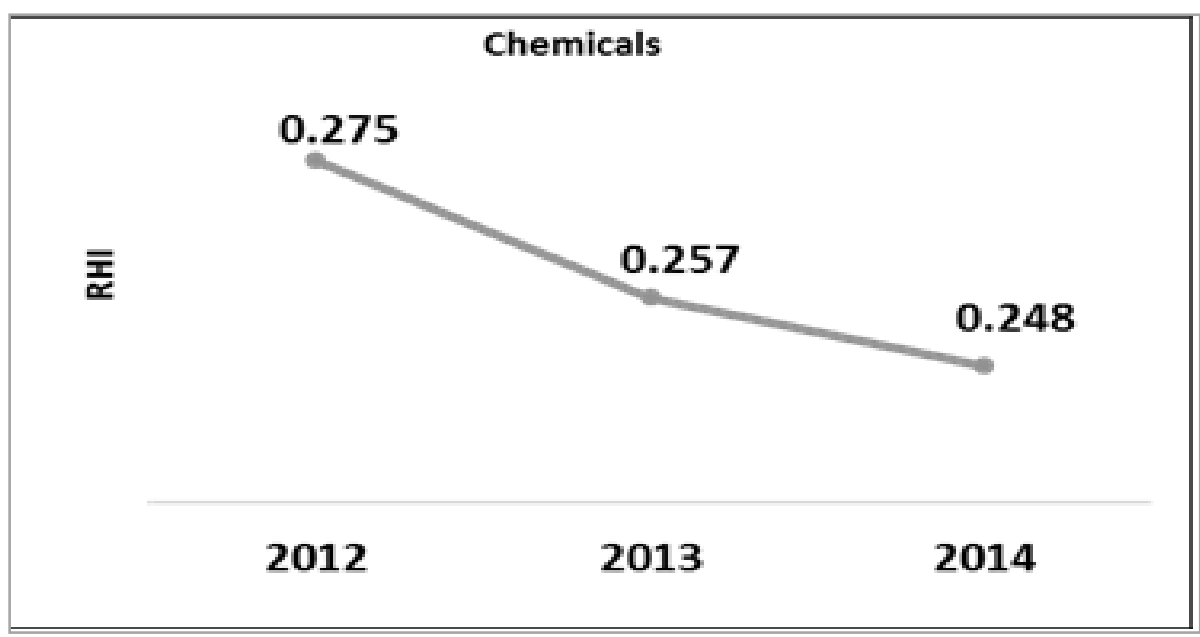

Source: Authors' calculations

Table 8: Number of Export Markets for major Indian Chemicals

\begin{tabular}{|c|c|c|c|}
\hline \multicolumn{4}{|c|}{ No. of Export Markets } \\
\hline Year & $\mathbf{2 0 1 2}$ & $\mathbf{2 0 1 3}$ & $\mathbf{2 0 1 4}$ \\
\hline Chemicals & 91 & 105 & 114 \\
\hline
\end{tabular}

Source: Trade Map database

\subsection{Over-reliance on fewer products: Sectoral Hirschman Index (SHI)}

India has not been able to diversify its exports and has been relying on some of the chemicals within the selected major chemicals. The SHI had consistently increased for both the segments over the period 2012-14, implying lower diversification in the products, which makes it highly susceptible to volatility if the global demand for those depended chemicals tends to fluctuate due to variety of reasons such as shift towards a savvier producer and so on (Figure 5). India's reliance on fewer of the selected chemicals is depicted by rising numbers of SHI over the years. In the chemical segment, the rise in the Sectoral Hirschman Index was minute however consistent since 2012. SHI lands at 0.307 in 2014, wherein few commodities played the dominant role amongst major chemical exports for this aforementioned jump and held significant share since 2012. 
Figure 5: Sectoral Hirschman Index for Major Chemicals

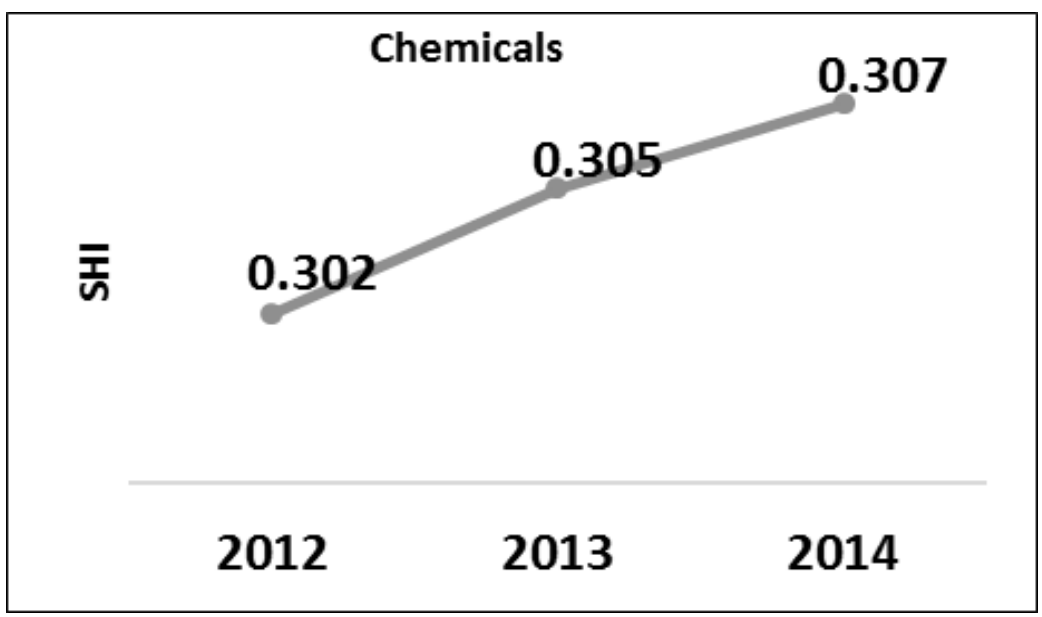

Source: Authors' calculations

\subsection{Resilient performance at Intra-Industry level: Grubel-Lloyd Index}

The time series of Grubel- Lloyd Index (GLI) of selected chemical products from India. Figure 6 shows that the value of GLI has remained around 0.4 to 0.5 from 2010 to 2014, which implies that our 40 per cent-50 per cent trade of major chemicals has been of intra-industry nature. It can be argued that by engaging in intra-industry trade, India can diversify exports not only across industries but rather within an industry and benefit from economies of scale. With respect to Indian chemical industries India can enhance its competiveness by further increasing the share of Intra-industry trade in Chemicals especially with its FTA partners.

\subsection{Quality margin}

To further evaluate the overall quality and sophistication of the major chemical exports, Quality Margin Map has been formulated to determine a prima facie position of the selected Indian chemicals globally. The quality margin map depicts change in market share on $\mathrm{X}$-axis and change in unit value on Y-axis (Figure 7). In addition, map is divided into four quadrants: Top-right quadrant displays the High Quality products whose market share has risen despite rise in the unit value, top-left and bottom right quadrant displays Normal quality products which exhibits characteristics of negative demand-price relationship, and bottom-left quadrant displays the Giffen/Low quality products. 
Figure 6: Grubel-Lloyd Index for Major Chemicals

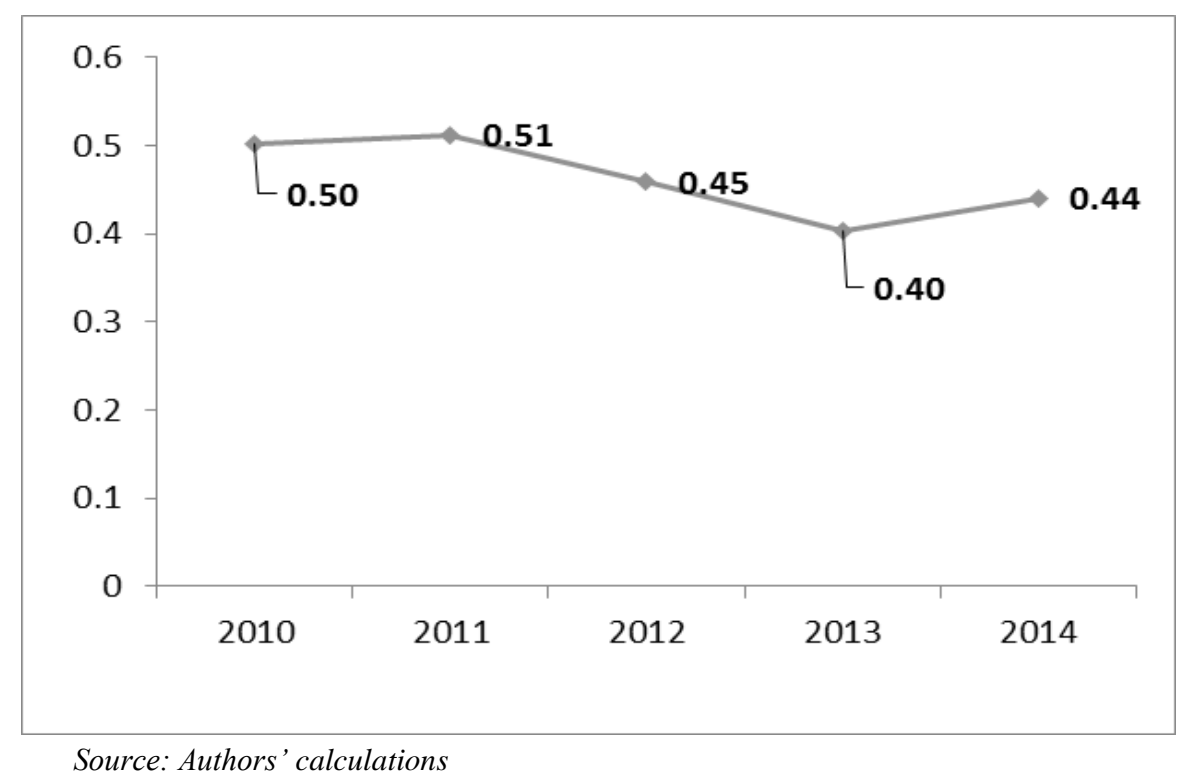

Figure 7: Quality Margin for Major Chemicals (2012-2014)

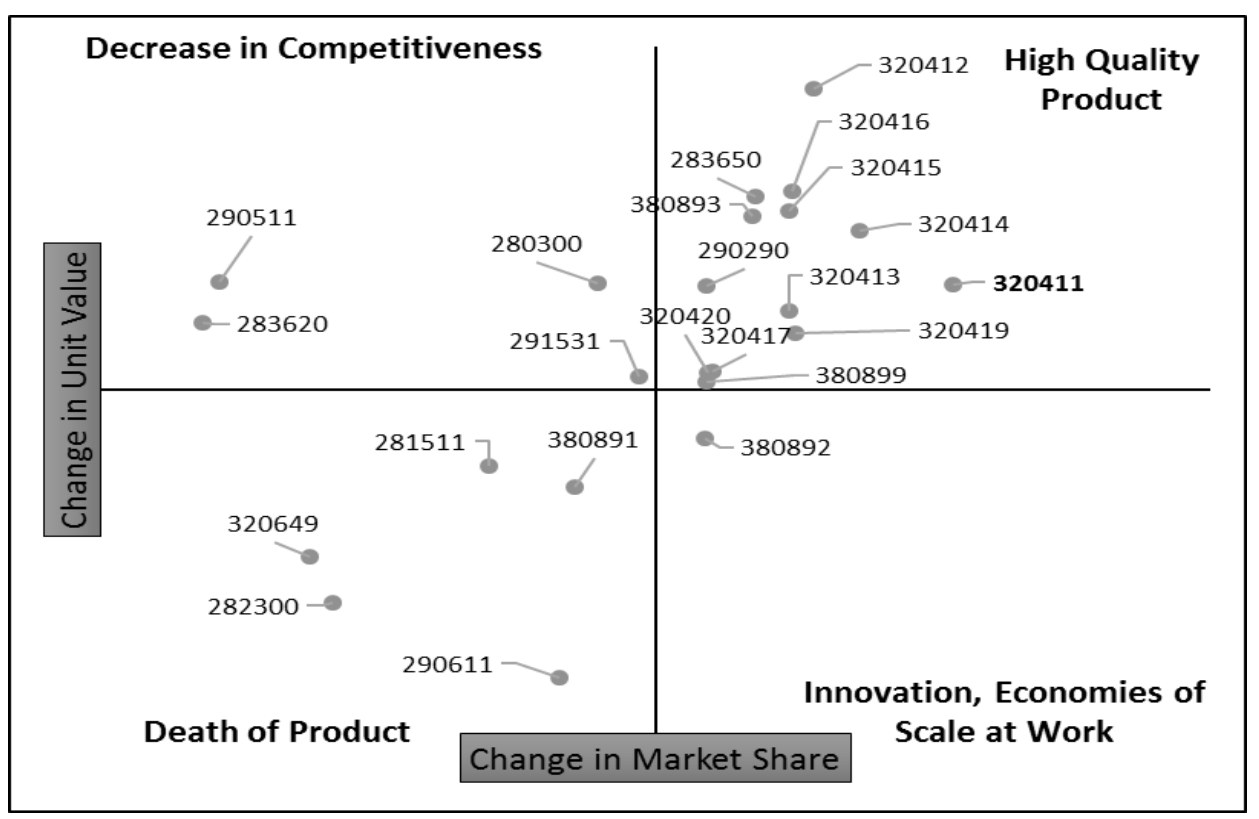

Source: Authors' calculations 
Each quadrant emanates particular and relevant features related to the products, which assists in determining possible reasons for the performance of the very product. In the chemicals market segment, major chemicals exported by India are mapped on the Quality Margin Map. There are 13 identified major chemicals, out of 23 major chemicals exported by India, which portrayed the traits of high quality products. Among major chemicals, unit value of Synthetic Organic acid dyes (320412) rose sharply by 35 per cent between 2012 and 2014, which translated into rise of export market share by 17 per cent. Similar trend was displayed by Synthetic Organic disperse dyes (320411) that accounted for a rise of 12.11 per cent in unit value and was accompanied by much sharper rise in market share by 32.20 per cent during 2012-2014. For major Dyes and Pigments, India's market share in global exports remained significantly high in twodigits.

Major chemicals under the High Quality quadrant reflect robust characteristics in world scenario. Despite on an aggregate level these products are treated as high quality, India's share in the top importing countries remained astoundingly low barring a few exceptions such as 320412, 320414, 320416, and 320420 (Table 9). For instance, India ranked $2^{\text {nd }}$ or $3^{\text {rd }}$ in terms of market share in top importers of 320411 but the share captured by India was menial at 2.3 - 5 per cent in 2014; outperformed by China. India also performed well in 320417, 320419 and 320420. Despite being the biggest importer of 320415 in 2014, India's chemical industry was able to export significant share to other top peer importers and ranked $2^{\text {nd }}$ and $3^{\text {rd }}$ in Germany and Brazil, respectively.

The most fascinating analysis had been for 290611 wherein India's performance at global level plummeted according to the quality margin map. However, India's share in top importing markets such as China and USA remained at an exorbitant of 81.1 per cent and 41.3 per cent in 2014, ranked at number 1 in 2012, 2013 and 2014 as well. The commendable performance of 290611, despite being high in the past 3 years, is gradually dropping. This indicates that India is losing its edge in its top export product, in this case, to USA whose share rose to 22 per cent in 2014 from 3.9 per cent in 2012.

\subsection{Conclusion}

Chemical industry plays a vital role in the functioning of most of the key sectors of an economy which includes agriculture, infrastructure, healthcare, textiles among others. People today lead more comfortable life due to the presence of chemical products almost in all spheres of life. A variety of global economic and regulatory forces influence changes in chemical production, transport, import, export, and their use and disposal. 
Table 9: List of Chemical Exports exhibiting High Quality and Economies of Scale

\section{Characteristics from India}

\begin{tabular}{|c|c|c|c|c|c|}
\hline \multirow[t]{2}{*}{ Product } & \multirow[t]{2}{*}{$\begin{array}{c}\text { Top Importing } \\
\text { Nations }\end{array}$} & \multicolumn{3}{|c|}{$\begin{array}{c}\text { Share in export of product } \\
\text { to the World }\end{array}$} & \multirow[t]{2}{*}{ CAGR } \\
\hline & & 2012 & 2013 & 2014 & \\
\hline \multirow[t]{5}{*}{320412} & Italy & $21.0 \%$ & $22.8 \%$ & $24.8 \%$ & $48.5 \%$ \\
\hline & Spain & $9.0 \%$ & $9.4 \%$ & $9.1 \%$ & $36.9 \%$ \\
\hline & Brazil & $6.5 \%$ & $6.4 \%$ & $6.1 \%$ & $31.8 \%$ \\
\hline & USA & $5.3 \%$ & $4.8 \%$ & $5.4 \%$ & $37.3 \%$ \\
\hline & Turkey & $4.0 \%$ & $5.1 \%$ & $4.6 \%$ & $44.9 \%$ \\
\hline \multirow[t]{5}{*}{320411} & Pakistan & $8.6 \%$ & $10.8 \%$ & $18.9 \%$ & $119.2 \%$ \\
\hline & China & $11.3 \%$ & $13.5 \%$ & $12.0 \%$ & $52.3 \%$ \\
\hline & South Korea & $3.6 \%$ & $3.0 \%$ & $8.2 \%$ & $125.1 \%$ \\
\hline & Honduras & $10.5 \%$ & $10.3 \%$ & $7.9 \%$ & $27.9 \%$ \\
\hline & Indonesia & $7.2 \%$ & $13.7 \%$ & $7.0 \%$ & $45.6 \%$ \\
\hline \multirow[t]{5}{*}{320419} & USA & $15.5 \%$ & $15.3 \%$ & $14.5 \%$ & $14.2 \%$ \\
\hline & Brazil & $6.1 \%$ & $6.6 \%$ & $7.8 \%$ & $33.0 \%$ \\
\hline & UK & $5.8 \%$ & $5.6 \%$ & $5.3 \%$ & $12.3 \%$ \\
\hline & Indonesia & $5.0 \%$ & $5.1 \%$ & $5.1 \%$ & $19.1 \%$ \\
\hline & China & $4.9 \%$ & $5.4 \%$ & $5.0 \%$ & $18.8 \%$ \\
\hline \multirow[t]{5}{*}{320413} & USA & $12.3 \%$ & $9.6 \%$ & $9.5 \%$ & $6.2 \%$ \\
\hline & Pakistan & $3.8 \%$ & $6.9 \%$ & $7.6 \%$ & $71.7 \%$ \\
\hline & Indonesia & $3.6 \%$ & $4.4 \%$ & $6.1 \%$ & $57.5 \%$ \\
\hline & Italy & $5.8 \%$ & $5.3 \%$ & $5.4 \%$ & $16.3 \%$ \\
\hline & UK & $9.5 \%$ & $6.7 \%$ & $5.4 \%$ & $-8.9 \%$ \\
\hline \multirow[t]{5}{*}{283650} & Nepal & $11.0 \%$ & $20.5 \%$ & $27.0 \%$ & $81.2 \%$ \\
\hline & Saudi Arabia & $9.0 \%$ & $16.0 \%$ & $13.5 \%$ & $42.0 \%$ \\
\hline & Bangladesh & $8.1 \%$ & $10.7 \%$ & $10.7 \%$ & $32.7 \%$ \\
\hline & Nigeria & $3.1 \%$ & $3.5 \%$ & $6.4 \%$ & $65.4 \%$ \\
\hline & Philippines & $4.9 \%$ & $4.2 \%$ & $5.1 \%$ & $19.0 \%$ \\
\hline \multirow[t]{5}{*}{380892} & Belgium & $3.8 \%$ & $4.7 \%$ & $7.4 \%$ & $62.1 \%$ \\
\hline & France & $6.4 \%$ & $5.9 \%$ & $6.9 \%$ & $21.2 \%$ \\
\hline & Netherlands & $2.0 \%$ & $3.1 \%$ & $6.0 \%$ & $100.4 \%$ \\
\hline & Brazil & $2.4 \%$ & $4.1 \%$ & $6.0 \%$ & $83.4 \%$ \\
\hline & Uruguay & $6.8 \%$ & $7.5 \%$ & $5.0 \%$ & $-0.3 \%$ \\
\hline \multirow[t]{5}{*}{320416} & Turkey & $16.9 \%$ & $22.3 \%$ & $21.4 \%$ & $55.5 \%$ \\
\hline & Bangladesh & $11.5 \%$ & $10.5 \%$ & $11.9 \%$ & $40.0 \%$ \\
\hline & Honduras & $4.6 \%$ & $4.0 \%$ & $6.5 \%$ & $64.1 \%$ \\
\hline & Brazil & $6.7 \%$ & $5.7 \%$ & $6.4 \%$ & $34.1 \%$ \\
\hline & Pakistan & $5.6 \%$ & $5.1 \%$ & $5.5 \%$ & $36.7 \%$ \\
\hline \multirow[t]{5}{*}{320415} & Bangladesh & $12.9 \%$ & $11.1 \%$ & $11.5 \%$ & $21.0 \%$ \\
\hline & Japan & $1.7 \%$ & $6.5 \%$ & $10.7 \%$ & $217.0 \%$ \\
\hline & Germany & $8.4 \%$ & $11.2 \%$ & $9.8 \%$ & $38.1 \%$ \\
\hline & China & $10.7 \%$ & $7.3 \%$ & $9.2 \%$ & $18.4 \%$ \\
\hline & USA & $12.5 \%$ & $8.2 \%$ & $7.5 \%$ & $-0.6 \%$ \\
\hline
\end{tabular}


22 |FOCUS: Journal of International Business, Volume 4, Issue 1, January-June 2017

\begin{tabular}{|c|l|c|c|c|c|}
\hline \multirow{3}{*}{ Product } & \multirow{2}{*}{$\begin{array}{c}\text { Top Importing } \\
\text { Nations }\end{array}$} & \multicolumn{3}{|c|}{$\begin{array}{c}\text { Share in export of product } \\
\text { to the World }\end{array}$} & \multirow{2}{*}{ CAGR } \\
\cline { 3 - 6 } & & $\mathbf{2 0 1 2}$ & $\mathbf{2 0 1 3}$ & $\mathbf{2 0 1 4}$ & \\
\hline \multirow{3}{*}{320414} & USA & $15.9 \%$ & $11.8 \%$ & $13.2 \%$ & $16.8 \%$ \\
\cline { 2 - 6 } & Italy & $11.3 \%$ & $11.3 \%$ & $13.1 \%$ & $37.8 \%$ \\
\cline { 2 - 6 } & Germany & $10.8 \%$ & $12.1 \%$ & $12.5 \%$ & $38.1 \%$ \\
\cline { 2 - 6 } & Spain & $4.7 \%$ & $5.4 \%$ & $6.0 \%$ & $44.5 \%$ \\
\cline { 2 - 6 } & Indonesia & $4.8 \%$ & $3.8 \%$ & $4.6 \%$ & $25.4 \%$ \\
\hline \multirow{3}{*}{380893} & USA & $22.4 \%$ & $30.3 \%$ & $36.9 \%$ & $57.1 \%$ \\
\cline { 2 - 6 } & France & $7.8 \%$ & $9.0 \%$ & $11.4 \%$ & $48.2 \%$ \\
\cline { 2 - 6 } & Japan & $2.8 \%$ & $7.0 \%$ & $7.6 \%$ & $101.1 \%$ \\
\cline { 2 - 6 } & Australia & $5.3 \%$ & $6.8 \%$ & $6.4 \%$ & $34.6 \%$ \\
\cline { 2 - 6 } & Germany & $7.6 \%$ & $5.3 \%$ & $3.8 \%$ & $-13.0 \%$ \\
\hline \multirow{3}{*}{290290} & USA & $37.5 \%$ & $31.5 \%$ & $28.4 \%$ & $4.5 \%$ \\
\cline { 2 - 6 } & China & $28.3 \%$ & $28.5 \%$ & $23.6 \%$ & $9.8 \%$ \\
\cline { 2 - 6 } & South Korea & $0.6 \%$ & $0.5 \%$ & $9.4 \%$ & $360.6 \%$ \\
\cline { 2 - 6 } & Netherlands & $22.3 \%$ & $8.6 \%$ & $8.7 \%$ & $-24.8 \%$ \\
\cline { 2 - 6 } & Switzerland & $0.3 \%$ & $6.6 \%$ & $8.1 \%$ & $519.4 \%$ \\
\hline
\end{tabular}

Source: Authors' calculations

World has experienced a growing demand for chemical based production and processes. As a result global chemical output increased dramatically from US\$ 171 billion in1970 to US\$ 4.12 trillion by 2010 (UNEP: Global Chemical Outlook, 2013).

Indian chemical industry has also witnessed a robust growth in the past decade. Strong domestic demand, driven by increasing PPP, higher growth and expanding industrial activities have helped chemical industry to surge. As per the data provided by UNIDO, India's chemical industry is ranked as $6^{\text {th }}$ largest in the world and $3^{\text {rd }}$ largest in Asia. The industry is $14^{\text {th }}$ largest in terms of its global exports and $8^{\text {th }}$ in terms of imports. Though capacity utilisation is close to $80 \%$ in $2014-15$, the production grew quite slowly in last 5-7 years with a CAGR of around 2 percent only. Analysing the production and trade data together, it is observed that during 2007-08 to 2011-12, the growth of the industry was very much exports driven. However, since 2011-12, exports shrunk and industry growth is now pushed by large domestic consumption. Meanwhile, higher import dependency, has created a potential threat and a possible long term negative impact on the economy. As India has now implemented Free Trade Agreements with several potential exporters of chemical products, there are wide spread apprehension that domestic industry will face serious competition from foreign players.

The chemical industry is divided into three major groups: Basic Chemicals (organic, inorganic chemicals, dyes and pigments, alkali chemicals and other chemical intermediaries), Speciality Chemicals (paints, adhesives, electronic chemicals, water 
management chemicals, flavours and fragrances, etc.) and agro-chemicals (various pesticides and insecticides).

Globalisation has resulted in a significant impact on India's Chemical industry. In dyes and pigments, pesticides, synthetic fibres, aromatics, etc., India has a rising net exports. However, in large number of other products such as organic and inorganic chemicals, India is experiencing surge of imports. In general, we have observed that in chemical sector India has overall trade surplus. More precisely, India's trade surplus in chemical sector is either stagnant in some period or not increasing in a significant way in other period. India's import from some of the FTA partners is increasing but its exports in general remain sluggish. This has identified the most important barriers Indian products face in international market and developed generic strategies to counter them. At the import side, the paper has also made an attempt to analyse the effectiveness of trade defence tools such as anti-dumping duties in India.

During 2012-2014, import of chemicals grew by $8.37 \%$. During the same period import of alkali chemicals went by $12.5 \%$ on an average whereas CAGR of import of organic chemicals were $10 \%$ and that of pesticides was $7 \%$. India's imports have grown both from FTA and non-FTA partners. In post FTA situation both MFN and FTA tariffs got reduced. However, tariff spread between raw materials, intermediate and final goods have become thinner due to FTA. As a result, India has lost effective rate of protection in number of goods.

The erosion of effective rate of protection is expectedly higher in products which have relatively lower value addition. In this case competitive pressure provides potential threat to the products. However, different FTA partners have received gains in different products. In dyes and pigments, average final good duty is zero while importing from Thailand which leads to high erosion of protection. Protection is also low while importing from Singapore. Japan has distinct advantage in exporting some organic chemicals. On the other hand, Malaysia has huge advantage in exporting inorganic and organic chemicals. Among all FTA partners, duty reduction is very low on imports from South Korea. In fact, in some cases, FTA duty on South Korea is more than even MFN effective rate.

The Quality Margin analysis reveal that not all importable products have equal sustainability in terms of their recognition as high quality products or products with substantial scope of innovation and economies of scale. Some products fall in these two categories and India imports not only from FTA partners, several non-FTA partners have rising market share in India. As it is clear, many of these exporters don't have any FTA with India; our policy should be positioned at the global level not targeting FTA partners only. It is suggested that for these products India may develop better standards, more 
robust compliance mechanism and play with anti-dumping duties and countervailing duties to protect the domestic industry. In a globalised world tariff is increasingly a week instrument and sooner or later tariff level will be close to zero with fewer exception. Hence, India needs to develop more nuanced strategy considering WTO compatible nontariff measures.

India is net exporter in chemical sector and export grew by almost $10.4 \%$ in US dollar term on an average during the period 2012-2014. India's exports of dyes \& pigments, pesticides and insecticides have shown a rising trend. Since, 2011-12, net exports of alkali, inorganic and inorganic chemical products registered a steady negative trend. India's performance in some of the chemicals has been commendable such as in dyes and pigments. To understand resilience of India's exports, extensive and intensive margin have been calculated. This explains whether our market share is increasing in an old market or whether it is expanding in the new market. It is important to note that in case of top exportable chemical products India's extensive margin increased substantially but intensive margin dropped indicating that we are losing our position in existing markets and making attempt to have market access in new countries.

Trade Intensity Index for chemicals in ASEAN and SAARC markets has remained greater than one, but consistently falling. The trade structure and the indices suggest that India has not been able to perform well in its peer FTA partner's markets, especially in Alkali Chemicals with lower than 1 per cent share in the world exports. Regional Hirschman Index declined over the period of three years but Sectoral Hirschman Index increased over the same period, suggesting India has expanded to newer markets but intensified on fewer chemicals. Grubel-Lloyd Index to reflect intraindustry trade for chemical has increased and hovered around 0.5 between 2010 and 2014. This suggests slight shift towards intra industry trade implying an increase of two way trade with partner countries. These products are required to be nurtured as they may play an important role by connecting them to global value chain of final goods.

There has been a significant price advantage to many players and domestic demand in India also experienced a significant jump. Hence, India requires global strategy to protect the domestic industry. As tariff is no more a strong instrument to apply, India needs to work on developing WTO compatible standards and technical barriers. The reports identify that many of the surge of imports may not last for long. However, few products are of higher quality and foreign players have an advantage of huge economies of scale. To counter this onslaught India also needs to intelligently devise the incentive structure including developing chemical value chain within the country (through connecting clusters), subsidy for new technology, etc. It is also noted that due to high competitiveness in the international markets, companies are not 
encouraged much too aggressively to pitch for higher exports. In contrast, the report finds that there are many products in which India has distinct advantage and in several products, India's trade may be part of evolving global value chain in chemical products. Hence, rather than making attempt to protect domestic industry, it is necessary to equip them for global competition. This will help the industry in two ways: with increasing ability to counter imports and able to sail through in international market with rising exports.

\section{References}

Bhat, S. \& Narayanan, K. (2009). The paper on technological efforts, firm size and exports in the basic chemical industry in India. Oxford Development Studies, 37(2), 146150.

Dhanisha, M. \& Johnson, B. (2015). Chemical industry in the Indian context. International Journal in Management and Social Science. 3(3), 440-442.

Government of India. (2016). Chemical and Petrochemical Statistics at a Glance-2016. Department of Chemicals and Petrochemicals, Ministry of Chemicals and Fertilizers.

Reis, J. G. \& Farole, T. (2012). Trade Competitiveness Diagnostic Toolkit. World Bank. Retrieved from https://openknowledge.worldbank.org/handle/10986/2248

United Nations Economic and Social Commission for Asia and the Pacific (UNESCAP). (2007). Trade Statistics in Policymaking - A Handbook of Commonly Used Trade Indices and Indicators. Studies in Trade and Investment. Retrieved from http://artnet.unescap.org/artnet_app/ Handbook2.pdf

United Nations Environment Programme. (2013). Global Chemicals Outlook - Towarsd Sound Management of Chemicals. Retrieved from https://sustainabledevelopment. un.org/content/documents/1966Global\%20Chemical.pdf 